\title{
Chinese, Russian, and Turkish Policies in the Iranian Nuclear Dossier: Between Resistance to Hegemony and Hegemonic Accommodation
}

\author{
Moritz Pieper
}

\begin{abstract}
This article sheds light on the foreign policies of China, Russia, and Turkey towards the controversial Iranian nuclear program and analyzes to what extent their policies are indicative of a security culture that resists hegemony. While advocating a nonhegemonic security culture discursively, China, Russia, and Turkey still partially adhere to hegemonic power structures on a behavioral level. These states' policies are the outcome of a balancing act between resistance to hegemony and hegemonic accommodation. The analysis in this article nuances the idea that counter-hegemonic discourses of rising powers always herald a revisionist power transition. The article thereby makes a contribution to the scholarly debate about emerging powers and the coexistence between declining hegemonic powers and norm-shapers in the making.
\end{abstract}

Keywords Iranian nuclear program, hegemony, norm contestation, China, Russia, Turkey

\section{Introduction}

When in 2002, components of Iran's nuclear program came to light that were undeclared to the International Atomic Energy Agency (IAEA) and therefore in breach of Iran's Safeguards Agreements as a member of the Nuclear Nonproliferation Treaty (NPT), Western governments reacted with alarm. The U.S. government quickly warned of the danger of a possible military dimension to the Iranian nuclear program and started pressuring Tehran to fully cooperate with the IAEA. Through its public discourse, the United States began to securitize the Iranian nuclear file and publicly warned of an Iranian nuclear bomb. In the absence of direct U.S.-Iranian diplomatic relations, the Europeans engaged in diplomatic attempts to solve the emerging Iranian nuclear crisis-but to no avail. When the file was transferred to the United Nations Security Council (UNSC) 
in 2006, the format for negotiations changed from the E3 (Germany, France, Great Britain) to the P5+1 (the five permanent UNSC members plus Germany). Cooperation with Russia and China on approaching Iran's nuclear file was now necessary and it soon became apparent that Moscow and Beijing favored different policies than those of the West. Other actors joined the Iran diplomacy at later moments with attempts to mediate between the West and Iran. Turkey was one of those mediators and engaged in a proactive phase of shuttle diplomacy and managed to secure the first Iranian agreement to a proposed nuclear deal in May 2010. In doing so, Ankara emphasized policies and diplomatic priorities that resembled the Chinese and Russian rhetoric more than the position of the U.S.dominated Western camp at the time.

This article sheds light on the Iran policies of China, Russia and Turkey, and more specifically, on their foreign policies towards the controversial Iranian nuclear program. While publically advocating a non-hegemonic security culture, China, Russia, and Turkey still partially accept hegemonic structures because of a level of material and political dependence on the United States. The author's argument in this article nuances the idea that counter-hegemonic discourses of rising powers always herald a revisionist power transition. It will be argued instead that their policies are the outcome of a balancing act between resistance to hegemony and hegemonic accommodation.

For a number of reasons, the choice of case studies in this article is illuminating for an analysis of a security culture that resists hegemony. First, the diplomacy surrounding Iran's nuclear program is a contested policy domain and arguably serves as a microcosm for resistance to a U.S.-dominated world order where key paradigms of U.S. foreign policy are challenged. Second, the Iranian nuclear crisis reveals contentions about world ideology and the status of Iran in international relations. Especially with a view to complicated U.S.Iranian relations, an analysis of contestation of U.S. policies in this case sheds light on challenges to U.S. conceptions of world order and Iran's role therein. And third, it allows new theoretical insights into alternatives to hegemonic power structures and security cultures in a post-U.S. hegemony world. It will be the aim of this article to elaborate on these points and to comparatively analyze the commonalities between Chinese, Russian, and Turkish policies in relation to Iran. Such a comparative analysis allows the author to draw conclusions on the extent to which Chinese, Russian, and Turkish foreign policies towards Iran's nuclear program are indicative of a security culture resisting hegemony.

The first section briefly outlines the foreign policies of China, Russia, and Turkey towards the Iranian nuclear program that was uncovered in 2002. The second section introduces the Coxian concept of hegemony and analyzes how China, Russia, and Turkey engage in normative disagreement with Iran sanctions regimes over their institutional nature. The third section shows how the "deWesternization" of Iran discourses is related to divergence from hegemony in 
its ideational dimension. A fourth section makes sense of Chinese, Russian, and Turkish partial convergence with hegemony in its material dimension. On the basis of this analysis, the final section analyzes the seeming ambiguity between the advocacy for counter-hegemonic security cultures on a discursive level and the partial adherence to U.S.-dominated governance structures on a behavioral level, and draws conclusions on the extent to which the Iran policies of China, Russia and Turkey resist hegemony. The research method comprises qualitative document analysis, complemented by semi-structured elite interviews with experts and decision-makers.

\section{Russian, Chinese, and Turkish Approaches to the Iranian Nuclear Crisis}

Russian, Chinese, and Turkish foreign policies towards the controversial nuclear program of Iran display a security culture that is different from a U.S.-inspired hegemonic security culture. When the hitherto undeclared Iranian nuclear program was uncovered in 2002, it did not take long for discursive dividing lines to emerge. While the Bush administration was pursuing an assertive foreign policy line on Iran, going so far as to threaten Iran with an attack and regime change (the incorporation of Iran into the infamous "Axis of Evil" being arguably the most dramatic and tangible discursive step in this process of securitization), China, Russia, and Turkey reacted with caution and were more hesitant to assume Iranian intentions on the basis of contested proliferation concerns. Yet, Russia, China, and Turkey held that pressure was not conducive to achieving greater cooperation by the Iranians concerning their nuclear file with the IAEA, and publicly reiterated that diplomacy was of the utmost importance for working towards a political solution of the emerging nuclear crisis.

Against the background of Russia's nuclear technology cooperation with Iran in the 1990s, following the break-up of the Soviet Union, Moscow made a distinction between what it regarded as legitimate nuclear cooperation and an alarmist securitization of Iran's nuclear program. From the beginning of the nuclear standoff in 2002, the Putin administration therefore emphasized the Iranian right to nuclear power (Putin 2003; Mousavian 2012, 163). When the nuclear file was then referred to the UNSC as a result of failed diplomatic attempts to solve the crisis, Russia worked together with China towards slowing down the pressure on Iran and watering down drafts of sanctions resolutions (Patrikarakos 2012, 224). The eventual adoption of sanctions resolutions bore witness to an increasing realization in Moscow and Beijing of Iranian delaying techniques and also to a level of receptiveness to U.S. pressure. In addition, Russian proposals to bring about political solutions (like the "Russian plan" of 2006, and Sergey Lavrov's step-by-step plan of 2011) are illustrative of Moscow's 
willingness to contribute to the diplomatic track and disperse tensions and war speculation (ElBaradei 2012, 137). ${ }^{1}$ And arguably, Iran's decision to turn the Russian plan down was one of the factors contributing to Russia's growing impatience with Iranian tactics and the impression that Moscow served as a diplomatic shield for Tehran in the UNSC (Mousavian 2012, 256-257). Critics of Russia's "good faith" diplomacy in Iran's nuclear dossier, however, have pointed out that Russia's monopolistic energy politics and its geopolitical power politics over the Caspian Sea account for a lack of genuine Russian interest in a longterm normalization of relations between Iran and the West. ${ }^{2}$ This has occasionally nurtured the impression that Russia was flirting with the idea of using the Iran nuclear talks as a vehicle for obstructionism in order to get concessions in other domains. Such an impression of the Iran nuclear talks as a bargaining chip was alluded to again in Deputy Foreign Minister Sergei Ryabkov's remarks, on March 20, 2014, on Russia's potential reconsideration of its position on the Iranian nuclear dossier in light of Western pressure over Moscow's Crimea policy.

Russia shows a reluctance to agree to international sanctions on Iran, yet conveys a desire to be perceived as a constructive player in the Iranian nuclear dossier. Further, it cannot be in Russia's interest to see a nuclear Iran emerge on its southern flank, since that would have obvious implications for the regional power balance and challenge Russia's nuclear monopoly in the region. Although a nuclear Iran cannot be in Russia's interest, Moscow does not support any plans for regime change. ${ }^{3}$ It is in this context that Russia has also worked to disperse war threats. Faced with dangerous rhetoric about pre-emptive strikes against Iran on the part of other stakeholders, Russia was incentivized to propose political solutions within the P5+1 format. It remains to be seen how Russian policy planning will react to the new chance for dialogue with the Rouhani administration and the possibility of a U.S. paradigm shift on Iran that will necessarily affect Russo-Iranian relations as well.

Similar to Russia, China was skeptical of U.S. rhetoric that began to securitize the Iranian nuclear file. China underlined the Iranian obligation to prove the exclusively peaceful character of its nuclear program, but refrained from departing from pre-conceived assumptions over Iranian intentions. In its official diplomacy, China repeatedly emphasized Iran's legitimate right to peaceful nuclear energy under Article IV of the NPT, criticized Western pressure on Tehran, and reiterated the importance of political dialogue (Dorraj and Currier 2008; Garver 2011, 81-84; Mazza 2011; Nourafchan 2010, 39; Swaine 2010, 6-8; Yuan 2006). China was also critical of what it perceived as double standards in nuclear diplomacy, with Iran being harshly criticized for its lack of transparency while the West remained silent on the nuclear activities of non-NPT members such as Israel, Pakistan, and India, amounting to what China criticized as "nuclear favoritism" (International Crisis Group 2010, 4). Against the backdrop of the controversial Iranian nuclear file, it was especially the Chinese supply to Iran of 
sensitive nuclear technology in the 1980s and 1990s that was viewed with concern by Western governments (ElBaradei 2012, 117). When the Iranian nuclear file reached the UNSC in 2006, China prevented quick condemnation of Iran and braked efforts to impose sanctions in what has been characterized as a "delayand-weaken” strategy (International Crisis Group 2010, 12). Like Russia, however, it eventually approved of resolutions that imposed a UN-backed sanctions regime on Tehran because of its continued lack of cooperation. And like Russia, the Chinese government does not accept additional unilateral sanctions imposed by the EU and the United States as being legitimate. ${ }^{4}$

In analyses of China's Iran policies, the importance of China-Iranian oil trade, commercial Chinese investments in Iran, as well as the exports of Chinese goods to Iran that fill the void created by unilateral Western embargoes are often emphasized (Burnam 2009; Chen 2010; Dorraj and Currier 2008; Djallil 2011; Garver 2011; International Crisis Group 2008; 2010, 5-7; Zhiyue 2012). After Saudi Arabia, Iran is China's second largest oil supplier. China is also benefitting from Western sanctions imposed on Iran, since Chinese companies are happy to step in and fill the void in the Iranian market. In this way, Beijing is seen as walking a tightrope between pursuing its commercial interests in Iran and showing receptiveness to international and Western security concerns. China is careful not to spoil its relations with the United States or to provoke perceptions that run counter to the official Chinese image of "peaceful development" by openly contravening existing sanctions lists. Also, like Russia, China did not hinder UNSC sanctions resolutions, trying to balance a pragmatic commercial approach to business in Iran with mollifying Western security concerns related to the Iranian nuclear program. Ignoring the latter would convey a disregard for Western perceptions not only of Iranian intentions, but also of Chinese foreign policy towards Iran, and fly in the face of China's public diplomacy pursuing an increasingly international profile that reflects the country's growing importance on the world scene. This is also evidenced by China's reduction of Iranian oil imports in order to qualify for U.S. sanctions waivers (Lohmann 2013, 4).

Unlike Russia and China, Turkey did not have the diplomatic leverage surrounding Iran's nuclear program that a permanent seat in the UNSC grants. Nevertheless, while the government in Ankara could not prevent or approve the imposition of international sanctions on Iran, its rhetoric resembled the cautious positions of China and Russia. Turkey criticized the use of sanctions as political tools in international relations, warned of unhelpful pressure on Iran, and emphasized that only political dialogue would achieve a long-term solution to the diplomatic crisis emerging over the nuclear program of neighboring Iran. ${ }^{5}$ Turkey's Iran policy has often been a balancing act between the need to uphold good-neighborly relations in line with Turkey's "Zero Problems with Neighbors" and "Strategic Depth" doctrines, as formulated by Foreign Minister Ahmed Davutoğlu, and a certain sensibility for Western security political concepts that 
alliance structures like Turkey's NATO membership indirectly imply (Pieper 2013a). In an attempt to negotiate a political solution to Iran's nuclear crisis, Turkey engaged in a process of proactive diplomacy and managed to secure the first Iranian agreement to a proposed fuel-swap deal in May 2010 (Parsi 2012, 172-209; Kibaroğlu 2010, 105-107). From early 2010 Turkey, together with Brazil, started negotiating as a mediator between Iran and the P5+1. Even though the U.S. administration was hesitant at first to accept Turkey as a mediator-largely due to Turkey's new regional assertiveness and Erdogan's occasional anti-Israel rhetoric - the U.S. State Department conveyed, as early as 2009, U.S. appreciation for any Turkish efforts to help alleviate tensions over the Iranian nuclear case (Parsi 2012, 181). As a nuclear fuel swap proposal by the Vienna group lost momentum in late 2009, Brazil and Turkey seized their chance for a diplomatic initiative, separately at first, then by way of a coordinated shuttle diplomacy beginning in January 2010 (ibid.). In addition, both had become nonpermanent members of the UN Security Council in 2010-a development that conveniently bolstered their political weight as mediators. The Turkish shuttle diplomacy with Tehran in 2009-2010 was an illustration of a remarkable foreign policy activism that served at least two purposes strategically. While assuring the United States that Turkey's commitment to international diplomacy was in line with Western security and non-proliferation priorities, ${ }^{6}$ Turkey's mediation also conveyed a prioritization of political dialogue. At the same time, it underlined the rejection of sanctions as a counterproductive means of pressuring the Iranians. The unexpected rejection of the May 2010 deal by the United States, and the subsequent imposition of UNSC sanctions resolution 1929 just one month later, frustrated Ankara and abruptly ended the short-lived episode of Turkish mediation in the Iran dossier. ${ }^{7}$

Turkey's foreign policy towards Iran is followed with a watchful eye in Washington. For example, the "gold-for-gas" deal between Iran and Turkey was seen as a Turkish attempt to circumvent the U.S. unilateral sanctions regime on Iran (Kandemir 2013). As much as Ankara shows receptiveness to the security perspectives of its NATO ally, the imperatives of geography (Iran as a neighbor) and of economic pragmatism (the need for oil and gas deliveries) impose constraints on Turkey's regional and general foreign policy. These constraints occasionally create a level of friction between the United States and Turkey over their respective approaches to Iran, even though Turkey hurries to emphasize the importance of solidarity with its U.S. ally. ${ }^{8}$

\section{Contesting Hegemony: Normative Disagreements with Iran Sanctions Regimes}

A Coxian understanding of hegemony proceeds from an analysis of its underlying material, ideational, and institutional structures. According to Cox, hegemony 
is "based on a coherent conjunction or fit between a configuration of material power, the prevalent collective image of world order (including certain norms) and a set of institutions which administer the order with a certain semblance of universality" $(1981,139)$.

The cases presented in this article show all three dimensions of a U.S. hegemonic security culture towards Iran that is being contested by China, Russia, and Turkey in different adaptations. It is at this point that a distinction between norms and rules should be made. Drawing on Katzenstein's $(1996,21)$ definition of culture as "a set of evaluative standards (such as norms and values) and a set of cognitive standards (such as rules and models) that define what social actors exist in a system, how they operate, and how they relate to one another," "norms and values" are here understood as concrete convictions and conceptions, while "rules and models" relate to the broader macro-structure that regulates the way these norms and values are communicated, applied, or changed. All three states advocate an adherence to the institutional framework of the UN system as embodying the underlying rules and models of international politics. Unilateral sanctions regimes, however, circumvent these rules and models. Contesting the legitimacy of extraterritorialized U.S. legislative action, therefore, becomes a normative divergence from hegemony. The U.S. unilateral sanctions regime in place is arguably the ultimate expression of hegemonic power structures. Initiated with the Iran Sanctions Act (ISA) of 1996 and extended to a comprehensive sanctions regime, the United States imposed punitive measures on other states that do business with Iran (Lohmann 2013) — an "imperial extension of American power and ... [a] sheer effrontery by which America sought to impose its political position," as Ali Ansari $(2006,144)$ puts it. Such a process of extraterritorializing U.S. legislation and enforcing political conceptions onto other states through compliance under the threat of economic costs is the epitome of hegemonic coercion on the basis of the U.S. predominance in the global trade, financial, and economic systems.

With regard to unilateral sanctions, a European External Action Service (EEAS) official remarked in an interview, "China and Russia explicitly do not share this sanctions policy." Chinese, Russian, and Turkish conceptions of legitimacy in this regard pertain to a desirable security culture that resists hegemonic politics. Thus, sovereignty and non-interference are norms that should govern international relations; they are the ideational underpinning of what would be a Coxian counter-hegemony. In this context, interference is not only understood as the physical intrusion into the territory of another state, as in the case of a military invasion, but equally captures the intrusive effect that a comprehensive sanctions regime can have on a country. As is the case with the Iran sanctions regime, such "secondary sanctions" even have an intrusive effect on third countries because of undesired interactions with the sanctioned entities.

Likewise, sovereignty is a concept whose link to hegemony is crucial; the 
rendition of enmity (i.e., the construction of an enemy image) is an orderconstituting exercise because it presupposes an acceptance thereof by a relevant audience (Williams 2003, 514; Campbell 1993; Klein 1994; Balzacq 2010). Being able to exert control over transgressions thus means being truly sovereign (Agamben 2002, 25; Schmitt 1993, 19). If China, Russia, and Turkey, therefore, reiterate legitimate Iranian rights to develop nuclear energy, they implicitly raise questions of sovereignty in that they question the non-granting of such rights on the part of hegemonic powers. Placing restrictions on nuclear fuel cycle development is perceived as encroachments on sovereignty. Russia's and China's advocacy for more "democratic" international relations is indicative of an effort to advance the ideational dimension of a security culture that resists hegemony, eliminates power asymmetries in international relations, and hence democratizes them. Chinese and Turkish warnings of the counterproductive effect of punitive and pressuring policies that undermine diplomacy are indicative of the same intent. China, Russia and Turkey have publicly advocated for a security culture that rejects politics of aggression vis-à-vis Iran and therewith have sought to "deWesternize" discourse on Iran. This will be the subject of the next section.

\section{The De-Westernization of Iran Discourses}

"Rationality" and "responsibility" in the international system are inherently subjective notions. The discursive usage of these terms, therefore, presupposes intersubjectively shared meanings. The narrative of an irrational, irresponsible Iranian leadership is a powerful example of the instrumentalization of a discourse on logic. States that do not share hegemonic values or political structures are labeled irresponsible, unreasonable, renegade counter-poles. Since the Islamic Revolution propelled an anti-American regime to power in 1979, Iran has been positioning itself in opposition to policies crafted by the West, and by the United States in particular. Both sides (Iran and the United States) have used this official rhetoric of mutual stigmatization for political reasons for the last three decades. The "axis of resistance" rhetoric, used to denote resistance to Israel and American presence in the Middle East, is illustrative of such a discursive construction of competing worldviews (Posch 2013,27). The social construction of statist identities for public relations purposes is often simplistic and even dualistic when combined with the means for foreign policy portrayal of an "enemy." What can be a self-proclaimed axis of resistance may be an Axis of Evil in an antagonistic discourse. Foreign policy discourse and state identities thus have to always be understood in a relational context.

China, Russia, and Turkey advocate for security cultures that do not necessarily coincide with hegemonic conceptions of the need to counter an irrational Iranian leadership said to pose a threat to peace and international 
security. Doing so, they have positioned themselves between an actor that explicitly resists hegemony (Iran) and the hegemon itself (United States). In this way, their foreign policy discourse has occasionally shown more appreciation for the Iranian perspective according to which the West aims to deprive Iran of technology that it has a legal right to use. Chinese, Russian, and Turkish public diplomacy can be read as a discursive attempt at desecuritization of the Iranian nuclear file. This diplomacy was also meant as an act of de-escalation of what was felt to be an emotionally charged, politicized discourse emanating especially from Washington. The Nuclear Non-Proliferation Treaty, as Patrikarakos (2012, 30) aptly writes, created a political fault line between the developed and the developing, the modernized and the modernizing world. Beyond technical and legal disputes about Iran's nuclear program and its rights and obligations as an NPT member, it is thus of paramount importance to understand the political and ideological dimensions of Iran's nuclear crisis. This is also key in understanding security cultures that resist political hierarchies created and sustained by a hegemonic "historic bloc" in the 20th century, and of which the NPT as a freezing regime of the nuclear status quo is a prime example. In a neoGramscian understanding of hegemony in international relations, the prevalence of dominant structures that are accepted and sustained by a sufficiently large number of other actors (states) constitutes a historic bloc. To the extent that other states act upon, sustain, and reinforce U.S.-dominant structures in the social, economic, and political sphere, U.S. hegemony post-1945 has brought about a historic bloc in a Gramscian understanding.

In their foreign policies towards Iran's nuclear program, China, Russia, and Turkey are thus resisting the ideational dimension of hegemonic structures. Their acceptance of the rules of the UN system, however, demonstrates their adherence to the institutional dimension of the broader macro-structure through which international politics are channeled, conveyed and communicated, as shown in the previous section. The Chinese and Russian approval of international sanctions in the UNSC is a case in point. While UNSC-backed international sanctions were approved with their consent, additional unilateral sanctions efforts are seen as illegitimate. Besides these ideational and institutional dynamics, the third dimension of Coxian hegemonic structures is one that explains a seeming contradiction in the advancement of such a resistance to hegemony, and therefore requires some elaboration.

\section{Non-Western Iran Policies in a Period of Hegemonic Decline}

The previous sections have examined the extent of Chinese, Russian, and Turkish adherence to the ideational and institutional aspects of the Coxian triangle of hegemonic structures. The following section turns to the third aspect of this 
triangle-the material dimension. A material dependence on the U.S.-dominated world economy explains behavioral deviation from foreign policies that resist hegemony. The official Russian Foreign Policy Concept, for example, bears a strong counter-hegemonic mark, as do repeated public statements indicating Russia's aversion to unilateral sanctions policies. "Another risk to world peace and stability is presented by attempts to manage crises through unilateral sanctions and other coercive measures, including armed aggression, outside the framework of the UN Security Council," the official Russian Foreign Policy concept formulates (Russian Foreign Ministry 2013). Unilateral sanctions are regarded as "illegitimate," as confirmed by Russian foreign ministry officials. ${ }^{10}$ The latter not only complicate diplomacy, in Moscow's thinking, but also have a negative effect on Russian companies' business dealings with Iran. Russian companies have been sanctioned for being seen as undertaking unwanted trade relations with Iran (Defense Industry Daily 2006). ${ }^{11}$ An example of Russian flexibility and (temporary) compliance with U.S. approaches towards Iran was the non-delivery of the S-300 defense system as a result of the U.S.-Russian "reset policy" that allowed closer cooperation on the Iranian nuclear file (Parsi 2012, 94). ${ }^{12}$

China is dependent on Iranian oil imports, and its trade with Iran in the weapons and nuclear technology fields has long been regarded with suspicion in the West. However, Beijing shows a receptiveness to direct and indirect pressure coming from Washington; as much as China is dependent on Iranian crude oil supplies, policy-makers in Beijing are cautious not to overstep the mark set out by U.S. Iran sanctions (Pieper 2013b, 315). The Chinese reduction of Iranian oil imports in order to qualify for U.S. sanctions waivers against Chinese companies (Lohmann 2013,4) is a forceful case in point for an adherence to a U.S. normative framework. Besides the material motivation, such compliance arguably has to do with the perception of China's foreign policy and with the impression that China is striving to behave like a "responsible stakeholder" in a hegemonic reading. From a hegemonic perspective, responsibility is attributed to actors that subscribe to the norms of the hegemon, irresponsibility to those that disregard them.

Turkey shares with China and Russia an aversion to Western pressure on Iran. Thus, the government in Ankara has always found itself at a strategic crossroads dictated by its geographic location on the one hand, and its integration into NATO alliance structures and a commitment to Western security policies on the other. Emphasizing that sanctions are counterproductive political tools to force Tehran to the negotiating table, Turkey engaged in a phase of proactive mediation in 2009 and 2010. This was intended to reduce tensions and propose diplomatic initiatives to the Iranian nuclear standoff. Even though securing the historic first Iranian agreement to a proposed deal in May 2010, this episode of Turkish mediation ended as a policy failure when UNSCR 1929 was adopted only a month later. The subsequent retreat from an active role as mediator-while not shying away from venting its disappointment with Western impatience- 
was proof of Turkey's alignment with U.S. positions. Given this stance, Turkey constantly finds itself in need of justification for its imports of Iranian oilcontrary to U.S. efforts to convince its allies of its economic isolation policies vis-à-vis Iran. While showing receptiveness to U.S. intentions, Turkey does not cut off the most cost-effective oil imports from neighboring Iran. Geographic and economic considerations partially trump perceptions of solidarity with U.S. policies.

This is an important observation that explains perceived inconsistencies in the Iran policies of states like China, Russia and Turkey when filtered through a Western lens. While these states have advocated for foreign policy approaches to address Iran's nuclear program different from those of the United States, they have still faced the imperatives of certain material constraints; Turkey cannot ignore the geographic imperatives that come from its location as Iran's neighbor and its ensuing dependence on Iranian oil imports. The integration into the international financial system as part of the U.S.-dominated international economic governance structures is another such material constraint. This is illustrated by the effect of unilateral sanctions on Chinese, Turkish, and Russian companies trading with Iran. Were China, Turkey and Russia cut off from the international trade and financial system, the sanctions regime would not affect them to the extent that it intends. Consequently, it is not unreasonable to assume that their reaction to, and public diplomacy regarding, such intrusive measures would be different.

Turkey repeatedly called for a political solution to the Iran nuclear crisis, emphasized the importance of diplomacy, and warned of the counterproductive effect of sanctions, but nevertheless showed solidarity with the United States, as Turkish announcements about the reduction of Iranian oil imports demonstrated (Habertürk 2012). Turkey complied with Iran sanctions, even though this compliance was "costly," as formulated by a Turkish foreign ministry official. ${ }^{13}$ China and Russia put the brakes on sanctions efforts in the UNSC, watered down resolutions and condemned pressure on Iran, and showed a stronger public anti-U.S. posturing than Turkey did. On a behavioral level, however, China and Russia also complied with U.S. policies, as the Chinese qualifications for the U.S. sanctions waivers, or Russiass renouncing of the S-300 sale to Iran, demonstrated.

A discrepancy between discursive and behavioral levels can therefore be observed. A public advocacy for resistance to hegemonic policies is paralleled by compliance on a behavioral level. Grudging acceptance of a U.S.-inspired sanctions regime on Iran allows China, Russia, and Turkey to collectively join the camp of "responsible" states because they adhere to material structures put in place for (U.S.) politico-ideological reasons. A normative disagreement with U.S. hegemonic structures, therefore, did not entail an all-out rejection of U.S. policies towards Iran. It was, instead, the relative dependence on the United States that led China, Russia, and Turkey to tacitly accept parts of a hegemonic security culture despite this being against their normative conceptions. Variation 
in norm compliance on the part of the case study states has to be seen in the context of their respective bilateral ties with the United States, the perception of their foreign policies toward Tehran and elsewhere, and their stakes in avoiding a confrontation with Iran. These stakes are, as has been shown, both material and ideational. It is the construction of norm perception that influences material imperatives pertaining to adherence or rejection of hegemonic structures, and vice versa. This observation harks back to the reciprocal effects between ideational, material, and institutional underpinnings of power structures in a Coxian understanding of hegemony. ${ }^{14}$ Rather than singling out one dominant side of the equation, it is the joint effect of these factors that needs to be taken into account for an understanding of Chinese, Russian, and Turkish policies in relation to Iran.

Suffice it to note that this is not meant to imply that the Iran policies of China, Russia, and Turkey are crafted in a joint effort to challenge the U.S.dominated system of governance. Rather than theorizing on counter-hegemonic bloc movements, it is arguably a more insightful endeavor to analyze the respective interactions of foreign policies with hegemonic power structures and to examine their collective effect on the crafting of a security culture that resists those structures-even though these foreign policies have their different motivations, constraints, and preconditions.

\section{Contesting Hegemony and Moving into a Post-American World}

Iran's nuclear crisis is not about physics, but about hegemonic politics and about a conflict whose resolution will have far-reaching implications for the dialectic between the modernizing and the modernized world. It will also affect perceptions of world order in a process where the U.S. role as a shaper of world hegemony is declining.

At the heart of the Cold War over Iran's nuclear program lie over three decades of traumatized U.S.-Iranian relations. Technical solutions to end this nuclear crisis have been proposed, discussed, and rejected. It is the mistrust on both sides that prevents any politically easy solution to a crisis whose resolution will entail a new chapter in U.S.-Iranian relations. Iranian Foreign Minister Zarif once more reminded the assembled decision-makers at the 50th Munich security conference, in January 2014, that the West does not have a "monopoly over mistrust." Only mutually acceptable proposals to craft a nuclear "endgame scenario" for Iran will succeed in ending what Zarif called, in late 2013, an "unnecessary crisis." The replacement of the confrontational rhetoric of the Ahmadinejad administration by a conciliatory tone under Rouhani's leadership has allowed a historically constructive dialogue with Iran that marks a new phase in the decade-old nuclear crisis, and that led to the first interim agreement 
on Iran's nuclear program in November 2013. Against the backdrop of these dynamics, a Russian foreign ministry official remarked in an interview that the U.S. position had embraced an approach that Moscow had already been advocating for years. ${ }^{15}$ Dmitri Trenin (2014) even writes that "the U.S. adoption of a gradualist approach toward Iran that Russia had long favored resulted in a breakthrough on the Iranian nuclear issue." Historic developments beginning in the late summer 2013 thus make it all the more relevant to reflect on foreign policies that resist hegemony. This is a most timely endeavor at a time when the world is witnessing a shift in hegemonic structures as P5+1 talks with Iran aim to hammer out a comprehensive nuclear solution with Iran to succeed the Joint Plan of Action of November 2013.

It is no wonder that Western observers of Russian, Chinese, or Turkish foreign policies cannot but conclude that their policies appear ambiguous. States that sit on fences because they are torn between different security cultures, strategic circles, or geographic crossroads are bound to pursue multidirectional foreign policies. To the outside observer, these policies occasionally appear incoherent or opportunistic at best, and politically unfaithful at worst. Exclusive and essentially simplistic categorizations are a recurring mantra of foreign policy projections and rhetoric. It has been shown in this research how an investigation into Chinese, Russian, and Turkish policies toward Iran can offer more nuanced understandings of foreign policies between such exclusive camps.

The decline of hegemony and "the rise of the rest" are too often portrayed in dichotomous terms. Studies of the BRICS and "emerging powers" typically analyze the changing international economic system in a multipolar world and the shift of power equations that growing economies of emerging powers bring along. This stream of literature has brought hegemonic transition theory and power transition theory-in the context of systemic leadership contestation by newly emerging powerful states - to renewed scholarly attention. ${ }^{16}$ Understanding foreign policies that are not "Western" and do not necessarily share the same normative framework with a Gramscian historic bloc-but still work with the rules of the system instead of working to overthrow them-requires a more differentiated perspective on the dynamics of gradual power shifts. The coexistence of established and emerging powers will inevitably determine the design of the future world order. Research is needed to examine this relationship beyond the accommodation-confrontation spectrum.

It is in precisely this context that Richard Sakwa (2011) has coined the concept of "neo-revisionism" to make sense of foreign policies that do not directly question or challenge the essence of the international system (as revisionist states would do), but indirectly aim to revise its functioning. In a similar vein, Serfaty $(2011,18)$ describes China and Russia as "prudent revisionist powers." Such concepts aim to avoid over-theorizing about foreign policies that do not coincide with that of the "system leader" as expressions of the advancement of alternative 
norms in international security governance.

Torn between resistance and accommodation, and under the constraints of the current political momentum, temporary as well as structural perceptions, and the imperatives of history, the foreign policies of China, Turkey, and Russia in the Iranian nuclear dossier cannot but appear as "essentially ambiguous" when filtered through a Western lens. ${ }^{17}$ The U.S. leadership role is declining, but an entirely alternative international order is not yet in sight. As long as the U.S.dominated historic bloc exists, China, Russia, and Turkey will work with and through the international architecture in place. This does not mean that these states will accept the same norms. An acknowledgment thereof allows for the debunking of confrontational policy rhetoric and for more nuanced research on post-hegemonic power shifts. It also transcends the unhelpful divide between "norm-setter" and "norm-taker," and helps us to reflect more accurately on the future coexistence between former hegemonic and emerging powers.

\section{Conclusion}

This article has carved out the commonalities in Russian, Chinese, and Turkish resistance to a consensual hegemonic order as demonstrated by a comparative analysis of their foreign policies towards the Iranian nuclear program. For hegemonic power structures to become established and sustained over time, they presuppose an acceptance by a sufficiently large number of other actors. The acceptance of such structures constitutes what Cox calls a "historic bloc" (Cox 1996, 131). By implication, the rendition of enmity becomes order-constituting in hegemonic systems; i.e., it serves to sustain the structures in place and to reconfirm prevalent ideologies. Challenging such a rendition of enmity, therefore, is akin to resistance to hegemony, as this article has tried to show.

A twofold distinction between a discursive and a behavioral level has been made; while Chinese, Russian, and Turkish officials publicly advocate for an adherence to a security culture that emphasizes compliance with the norms of "sovereignty" and "non-interference," their level of material and political dependence on the United States prompts them to follow foreign policies that still comply with U.S. hegemonic structures. The U.S. unilateral sanctions regime and compliance with extraterritorialized U.S. legislation is the most prominent case in point.

Russia, since the discovery of Iran's hitherto covert nuclear program in 2002, has emphasized the Iranian right to use peaceful nuclear energy and, until the referral of the Iranian nuclear file to the UNSC and the adoption of first Security Council resolutions, has largely shielded Tehran from international pressure-as has China. While Western governments observed Russian-Iranian nuclear technology cooperation with a watchful eye, Moscow continued to 
make a distinction between legitimate commercial ties and an alleged military dimension of Iran's nuclear program. Likewise, Chinese provision of sensitive nuclear technology to Iran, as well as its commercial exploitation of Western embargoes on Iran and its dense ties with the Iranian oil economy, have been seen as undermining Western attempts to increase international pressure on Iran. Turkey presents itself as a U.S. ally in the region and is committed to NATO alliance structures. Materially, its location as a geographic neighbor of Iran and the imperatives of economy, however, impose constraints on Turkey that make Ankara disagree with Western politics of securitization of Iran's nuclear program. In political discourse, however, Turkey has emphasized the importance of political dialogue to solve the Iranian nuclear crisis and has been skeptical of the use of pressure and sanctions on Iran.

Chinese, Russian, and Turkish foreign policies toward the Iranian nuclear program arguably breathe the ambition to partially "de-Westernize" security cultures and discourses toward Iran. On a discursive level, their foreign policies display a normative divergence with a U.S.-inspired security culture towards Iran. At the same time, one must be careful not to over-theorize on indications of counter-hegemonic forces struggling to topple the prevailing power system. Respective foreign policy motivations are diverse. The "de-Westernization" of Iran discourses is therefore not to be confused with a joint endeavor to create a counter-hegemonic bloc opposing U.S. leadership.

China, Russia, and Turkey resist a hegemonic security culture on a discursive level. Advocating for a non-hegemonic security culture conveys a normative divergence, a deviation from hegemonic normative frameworks. Their relative dependence on the United States, however, leads China, Russia, and Turkey to follow foreign policies that accept parts of a hegemonic security culture. The implementation of the international sanctions regime, even though potentially contrary to their economic interests, and, even more tellingly, the Chinese and Turkish reduction of Iranian oil imports in order to qualify for U.S. unilateral sanctions exemptions, are cases in point. Partial acceptance of such hegemonic structures is predicated upon a level of political and material dependence on the United States. And the acceptance of UN-backed international sanctions explains a convergence of rules that are still accepted as governing international relations at large. This seeming variation in norm compliance is visualized by a two-level

Table 1. Two-level Model to Capture "Resistance to Hegemony"

\begin{tabular}{l|l|l}
\hline \hline & \multicolumn{1}{|c|}{ Discursive level } & \multicolumn{1}{c}{ Behavioral level } \\
\hline $\begin{array}{l}\text { Adherence to security } \\
\text { culture }\end{array}$ & $\begin{array}{l}\text { Advocacy for non-hegemonic } \\
\text { security culture }\end{array}$ & $\begin{array}{l}\text { Compliance with a U.S.-inspired } \\
\text { hegemonic security culture }\end{array}$ \\
\hline $\begin{array}{l}\text { Degree of resistance to } \\
\text { hegemony }\end{array}$ & $\begin{array}{l}\text { Normative divergence with } \\
\text { hegemony }\end{array}$ & $\begin{array}{l}\text { Rules convergence with } \\
\text { hegemony }\end{array}$ \\
\hline
\end{tabular}


model to capture "resistance to hegemony," as shown in Table 1.

The coexistence of established and emerging powers will inevitably determine the design of the future world order. We are at a historic juncture where the working relationship between former hegemons and rising powers as potential challengers is already being re-balanced. In this regard, with different prioritizations and conceptions of legitimacy by the different actors involved becoming manifest, the Iranian nuclear crisis arguably is not only a battlefield for the survival of the NPT regime, but is a debate about differing conceptions of world order and security governance. Chinese, Russian, and Turkish foreign policies toward the Iranian nuclear program, as analyzed in this article, stand indicative of alternative security cultures toward Iran in a "process of power de-concentration" (Tessman and Wolfe 2011, 218) in which dominant power structures have not been replaced by alternative governance structures-yet. The resulting seemingly ambiguous variation in compliance with the norms advocated by the case study states themselves is to be explained by the friction between contestation and consent in a gradual process of U.S. hegemonic decline and power de-concentration. At a time when U.S. foreign policy on Iran seems to be undergoing a paradigm shift, such a finding sheds light on the dynamics of international power shifts that will, one way or another, determine international politics and the coexistence between declining hegemonic powers and normshapers in the making.

\section{Notes}

The original draft of this article was presented at the International Studies Association's 55th Annual Convention held in Toronto, March 26-29, 2014. The author thanks Licínia Simão and Mehran Kamrava for their helpful comments.

1. As also reiterated by a Russian foreign ministry official. Author's interview, Moscow, April 18, 2013.

2. Author's interview with high-ranking Swiss diplomat, Berlin, August 26, 2013; Author's interview with Dr. Walter Posch, SWP, Berlin, June 25, 2013.

3. Author's interview with Dr. Alexei Arbatov, Moscow, November 13, 2013.

4. Author's interview with Chinese foreign ministry official, Beijing, April 18, 2014.

5. Author's interview with high-ranking Turkish diplomat, Ankara, June 17, 2013. Cf. also Udum 2012, 103-106; Mercan 2009, 18-19; Kibaroğlu 2010, 4-6; Üstün 2010, 20; Larrabee and Nader 2013, 27.

6. Turkey could base its diplomacy on the consent of the Obama administration, as evidenced by a letter written by U.S. President Obama to Brazilian President Lula in April 2010 in which he explicitly welcomed Turkish-Brazilian diplomatic initiatives (Mousavian 2012, 383; Parsi 2012, 187).

7. Author's interview with Turkish high-ranking diplomat, Brussels, May 29, 2013.

8. Author's interview with Turkish foreign ministry official, Washington, D.C., February 
$14,2014$.

9. EEAS official, author's interview, Brussels, June 4, 2013.

10. Author's interview with Russian foreign ministry official, Moscow, April 18, 2013.

11. The sanctions against Sukhoi, imposed because of alleged violations of the Iran Nonproliferation Act of 2000, were lifted again in November 2006 (Ria Novosti 2007).

12. Dr. Alexei Arbatov, head of the Center for International Security at IMEMO, asserts that the S-300 decision was the "peak" of the U.S.-Russian reset policy. Author's interview, Moscow, November 13, 2013.

13. Author's interview, Washington, D.C., February 14, 2014.

14. And is also in line with a theoretical framework sympathetic to moderate constructivism.

15. Author's interview with Russian foreign ministry official, Moscow, November 12, 2013.

16. Seminal examples discussing global power shifts and prospects for international cooperation among power poles are Gilpin 1981; Organski 1968; Organski and Kugler 1980; Keohane 1984; Kagan 2002; 2012; Kupchan 2012.

17. Sakwa $(2002,366)$ has used this formulation to capture Russian foreign policy reorientations following the breakup of the Soviet Union.

\section{References}

Agamben, Giorgio. 2002. Homo Sacer. Die Souveränität der Macht und das nackte Leben, trans. Hubert Thüring. Frankfurt: Suhrkamp.

Ansari, Ali. 2006. Confronting Iran: The Failure of American Foreign Policy and the Next Great Conflict in the Middle East. New York: Basic Books.

Balzacq, Thierry. 2010. Securitization Theory: How Security Problems Emerge and Dissolve. New York: Routledge.

Burnam, Edward. 2009. China and Iran: Parallel History, Future Threat? Stroud: The History Press.

Campbell, David. 1993. Writing Security: United States Foreign Policy and the Politics of Identity. Manchester: Manchester University Press.

Chen, Wen-Sheng. 2010. “China’s Oil Strategy: 'Going Out' to Iran.” Asian Politics and Policy 2 (1): 39-54.

Cox, Robert. 1981. "Social Forces, States and World Orders: Beyond International Relations Theory." Millennium: Journal of International Studies 10 (2): 126-155.

Cox, Robert. 1996. Approaches to World Order. Cambridge: Cambridge University Press.

Defense Industry Daily. 2006. "US Ban on Russian Defense Firms Raises the Stakes." August 11. http://www.defenseindustrydaily.com/us-ban-on-russian-defense-firms-raisesthe-stakes-02522/ (accessed October 17, 2013).

Djallil, Lounnas. 2011. "China and the Iranian Nuclear Crisis: Between Ambiguities and Interests." European Journal of East Asian Studies 10 (2): 227-253.

Dorraj, Manochehr, and Carrier Currier. 2008. "Lubricated with Oil: Iran-China Relations in a Changing World." Middle East Policy 15 (2): 66-80.

ElBaradei, Mohamed. 2012. The Age of Deception: Nuclear Diplomacy in Treacherous Times. New York: Bloomsburg Publishing Plc. 
Garver, John. 2011. “Is China Playing a Dual Game in Iran?” The Washington Quarterly 34 (1): 75-88.

Gilpin, Robert. 1981. War and Change in World Politics. Cambridge: Cambridge University Press.

Habertürk. 2012. “Turkey to Cut Iran Oil Imports.” March 30. http://www.haberturk.com/ general/haber/729605-turkey-to-cut-iran-oil-imports (accessed April 1, 2013).

International Crisis Group. 2008. "China’s Thirst for Oil.” June 9. http://www.crisisgroup. org/en/regions/asia/north-east-asia/china/153-chinas-thirst-for-oil.aspx (accessed February 10, 2013).

International Crisis Group. 2010. "The Iran Nuclear Issue: The View from Beijing.” February 17. http://www.crisisgroup.org/en/regions/asia/north-east-asia/china/B100the-iran-nuclear-issue-the-view-from-beijing.aspx (accessed February 10, 2013).

Kagan, Robert. 2002. Paradise and Power: America and Europe in the New World Order. London: Atlantic.

Kagan, Robert. 2012. The World America Made. New York: Knopf.

Kandemir, Asli. 2013. "Exclusive: Turkey to Iran Gold Trade Wiped Out by New U.S. Sanction." Reuters, February 15. http://www.reuters.com/article/2013/02/15/us-iranturkey-sanctions-idUSBRE91E0IN20130215 (accessed June 10, 2013).

Katzenstein, Peter J., ed. 1996. The Culture of National Security: Norms and Identity in World Politics. New York: Columbia University Press.

Keohane, Robert O. 1984. After Hegemony: Cooperation and Discord in the World Political Economy. Princeton: Princeton University Press.

Kibaroğlu, Mustafa. 2010. “The Iranian Quagmire: How to Move Forward; Position: Resuscitate the Nuclear Swap Deal." Bulletin of the Atomic Scientists 66: 102-108.

Klein, Bradley. 1994. Strategic Studies and World Order: The Global Politics of Deterrence. Cambridge: Cambridge University Press.

Kupchan, Charles. 2012. No One's World: The West, the Rising Rest and the Coming Global Turn. Oxford: Oxford University Press.

Larrabee, Stephen F., and Alireza Nader. 2013. Turkish-Iranian Relations in a Changing Middle East. Santa Monica: RAND Corporation.

Lohmann, Sascha. 2013. “Unilaterale US-Sanktionen gegen Iran.” SWP-Aktuell 63: 1-8.

Mazza, Michael. 2011. "China-Iran Ties: Assessment and Implications for U.S. Policy." AEI Iran Tracker, April 21. http://www.reuters.com/article/2013/02/15/us-iran-turkeysanctions-idUSBRE91E0IN20130215 (accessed February 11, 2013).

Mercan, Murat. 2009. “Turkish Foreign Policy and Iran.” Turkish Policy Quarterly 8: 13-19.

Mousavian, Seyed Hossein. 2012. The Iranian Nuclear Crisis: A Memoir. Washington, D.C.: Carnegie Endowment for International Peace.

Nourafchan, Nicolo. 2010. “Constructive Partner or Menacing Threat? Analyzing China’s Role in the Iranian Nuclear Program." Asian Security 6 (1): 28-50.

Organski, Abramo Fimo Kenneth. 1968. World Politics. New York: Knopf.

Organski, Abramo Fimo Kenneth, and Jacek Kugler. 1980. The War Ledger. Chicago: University of Chicago Press.

Parsi, Trita. 2012. A Single Roll of the Dice: Obama's Diplomacy with Iran. Yale: Yale University Press.

Patrikarakos, David. 2012. Nuclear Iran: The Birth of an Atomic State. London and New York: I.B. Tauris. 
Pieper, Moritz. 2013a. “Turkish Foreign Policy toward the Iranian Nuclear Program: In Search of a New Middle East Order after the Arab Spring and the Syrian Civil War." Alternatives-Turkish Journal of International Relations 11 (3): 81-92.

Pieper, Moritz. 2013b. "Dragon Dance or Panda Trot? China's Position towards the Iranian Nuclear Program and Its Perception of EU Unilateral Iran Sanctions." European Journal of East Asian Studies 12 (2): 295-316.

Posch, Walter. 2013. "The Third World, Global Islam and Pragmatism: The Making of Iranian Foreign Policy." SWP Research Paper. Berlin: German Institute for International and Security Affairs.

Putin, Vladimir. 2003. "Intervyu Prezidenta Rossii V.V. Putina Amerikanskim telekanalam. Novo-Ogoreva” [Interview of American TV channels with Russian president V. Putin]. Bulletin of the Press Service of the Russian Federation, September 24.

Ria Novosti. 2007. "Moscow to Press U.S. for Sanction Cancellation - FM Lavrov." February 3. http://en.ria.ru/world/20070203/60158997.html (accessed October 17, 2013).

Russian Foreign Ministry. 2013. "Concept of the Foreign Policy of the Russian Federation." http://www.mid.ru/bdomp/ns-osndoc.nsf/1e5f0de28fe77fdcc32575d900298676/869c 9d2b87ad8014c32575d9002b1c38 (accessed January 15, 2014).

Sakwa, Richard. 2002. Russian Politics and Society. London and New York: Routledge.

Sakwa, Richard. 2011. "Russia and Europe: Whose Society?" Journal of European Integration 33 (2): 197-214.

Schmitt, Carl. 1993. Politische Theologie: Vier Kapitel zur Lehre der Souveränität. Berlin: Duncker \& Humblot.

Serfaty, Simon. 2011. "Moving into a Post-Western World.” The Washington Quarterly 34 (2): 7-23.

Swaine, Michael D. 2010. “Beijing's Tightrope Walk on Iran." China Leadership Monitor 33: 1-19. http://www.hoover.org/publications/china-leadership-monitor/article/35436 (accessed February 11, 2013).

Tessman, Brock, and Wojtek Wolfe. 2011. "Great Powers and Strategic Hedging: The Case of Chinese Energy Security Strategy." International Studies Review 13: 214-240.

Trenin, Dmitri. 2014. "Russia: Sealing the New Quality of Its Foreign Policy." Carnegie Moscow Center, January 20. http://carnegie.ru/eurasiaoutlook/?fa=54244 (accessed April 02, 2014).

Udum, Şebnem. 2012. “Türkiye’nin İran Nükleer Meselesindeki Siyaseti.” Ortadoğuz Analiz 43 (4): 98-107.

Üstün, Kadir. 2010. “Turkey’s Iran Policy: Between Diplomacy and Sanctions.” Insight Turkey 12 (3): 19-26.

Williams, Michael C. 2003. "Words, Images, Enemies: Securitization and International Politics.” International Studies Quarterly 47 (4): 511-531.

Yuan, Jing-Dong. 2006. "China and the Iranian Nuclear Crisis." China Brief 6 (3): 1-3. http://www.jamestown.org/programs/chinabrief/single/?tx_ttnews\%5Btt_ news\%5D=3926\&tx_ttnews\%5BbackPid\%5D=196\&no_cache=1 (accessed April 3, 2014).

Zhiyue, Bo. 2012. "China's Middle East Policy: Strategic Concerns and Economic Interests." Middle East Insight, April 19. http://www.mei.nus.edu.sg/publications/mei-insights/ chinas-middle-east-policy-strategic-concerns-and-economic-interests (accessed January 7, 2013). 
Moritz Pieper is a Ph.D. candidate in International Relations at the University of Kent, Brussels. He holds a B.A. in European Studies from Maastricht University, an M.A. in International Relations from the University of Kent, Canterbury, and an M.A. in International Relations in Euroatlantic and Eurasian Communities from the Higher School of Economics, Moscow. He has published in European Foreign Affairs Review, Alternatives-Turkish Journal of International Relations, and the European Journal of East Asian Studies. His op-eds and commentaries have appeared in openDemocracy, The Daily Star (Lebanon), The Atlantic Post, and The Moscow Times. E-mail: mp442@kent.ac.uk 